\title{
ACESSIBILIDADE AO CONHECIMENTO: FATOR DE IMPACTO PARA O DESENVOLVIMENTO HUMANO
}

No presente número da Revista Psicologia em Estudo queremos dar continuidade a um processo de reflexão que vem sendo desenvolvido, com vistas a uma Psicologia comprometida com os rumos que o ser humano particular e, também, a humanidade tomam. Consideramos este espaço editorial como de suma importância, seja porque introduz o que se apresenta no corpo da Revista, seja porque permite a exposição da missão por ela defendida.

Essa exposição nos parece fundamental, justamente por estarmos vivenciando um período de convocatória para que o trabalho intelectual se apresente de modo cada vez mais intensivo, por meio de diferentes tipos de publicações. Consideramos que o trabalho intelectual, assim constituído na sociedade de classes sociais antagônicas, antes de ser oposto ao não intelectual, deveria ser entendido como uma atividade que deveria lançar luzes sobre a prática social que vimos protagonizando. Dele esperamos teorizações ou elementos que a ilumine [prática social], nesse sentido, consideramos que seu compromisso seja o de pensar a prática, ou que ele deva ser a prática pensada.

Consideramos que os textos publicados contêm em si um quantum de sociabilidade, pois resultam de um trabalho, em tese, altamente criador. As investigações e os ensaios analíticos, além de revelarem o próprio investimento do autor e do seu grupo de trabalho, assentam-se nas elaborações humanas, registradas e repassadas ao longo da história, e que são por eles apropriadas. Lembramos que o acervo que permite a criação, a sua matéria prima, é composto pelas apropriações das criações humanas, cristalizadas ou objetivadas em incontáveis teorias, filosofias, obras de artes, ciências, etc. Essas apropriações e as novas objetivações que o autor/pesquisador elabora permitem o processo de formação do humano nos homens.

Estar sendo partícipe de um processo de criação teórica, seja como autor, seja como leitor permite que o desenvolvimento humano se encaminhe para estágios mais complexos. Tanto o psiquismo daqueles que escrevem como daqueles que lêem são transformados continuamente. Desse modo, cada texto, por mais individual que seja, tem o coletivo como ponto inicial e a ele deve retornar, de uma forma ou de outra.

Seguindo esse entendimento, podemos pensar que quanto mais rico for o mundo externo, quanto mais elaborações ele propiciar e quanto mais ele permitir a circulação das mesmas entre as diferentes classes sociais, tanto mais chances se têm de se formar o homem rico. Este pode ser entendido como tal, não por possuir necessariamente bens materiais, mas por ter sido nele criadas necessidades mais complexas que as de mera sobrevivência biológica.

Como humanidade, alcançamos um estágio tal de desenvolvimento e de contradição (por exemplo, a extrema riqueza sendo gerada, de um lado e, de outro, a produção de uma miserabilidade impensável) que fíca difícil não nos posicionarmos quanto aos rumos da ciência, bem como da acessibilidade aos seus produtos (como as publicações científicas) considerando-se o fator de impacto que tem para o desenvolvimento de todos os povos, ao lhes permitir outra forma de relacionamento entre si e com o mundo.

Buscamos fazer frente à prática de conformação de indivíduos a espaços que nem sempre lhes cabem, precisamos de maiores e melhores mediações, vencendo explicações inconsistentes que perpetuam idéias, que naturalizam ou que tornam biológico e individual tudo aquilo que é histórico e social. Entendemos que a tarefa essencial que ainda se impõe à Psicologia e à ciência em geral está, justamente, na explicitação das contradições próprias a esse momento histórico de capitalismo em crise, visto que levam os indivíduos a um determinado modo de existir e de se desenvolverem que nem sempre entendem, mas que reproduzem.

Pelo exposto, temos que a Psicologia, em sua vocação crítica, considera que o psiquismo se constitui socialmente e, para tanto, precisa de material para tal realização. Marcamos, enfim, a importância da veiculação dos saberes sistematizados, numa defesa por disponibilizá-los para que a riqueza genérica se realize nos homens particulares. 
Neste volume contamos com 20 textos que expressam, de um modo ou de outro, essa preocupação com o indivíduo, a família, o trabalho e a sociedade. Os autores são estudiosos que procuram responder às questões que se avolumam no plano individual e societário, e que as abordam sob diferentes perspectivas teóricas, por meio de análises, sínteses, reflexões.

Ante as preocupações apontadas, convidamos o leitor a se apropriar do conteúdo apresentado no presente volume e esperamos continuar em nosso propósito de termos a prática pensada e a teoria fortalecida. Boa leitura, bons estudos!. 